\title{
HOW DO THE NATIONAL TOURISM ORGANIZATIONS USE THE SOCIAL MEDIA?
}

\author{
Jan Hruška, Martina Pásková
}

\section{Introduction}

The National Tourism Organizations (NTOs) are key actors of destination management at national level. The complexity and professionalism of their involvement in tourism management has been growing in recent years, both in the field of the destination marketing and in terms of tourism promotion forms, support for statistics and tourism research. An important impetus and new opportunities for the development of NTO's activities represent new technologies, especially HDR photo and video, panoramic photos, virtual reality and mobile technologies, including extended reality. These technologies change the NTO marketing (Lange-Faria \& Elliot, 2012). New technologies are also part of the social media, the most dynamic element of the current NTO marketing and, more generally, the destination marketing at all geographical levels (Királ'ová \& Pavlíčeka, 2015). Social media bring new dimensions and challenges for marketing (Hofacker \& Belanche, 2016), including destination marketing (Munar, 2012; Palatková, 2012; Tham, Croy, \& Mair, 2013; Pike \& Page, 2014). Social media also significantly influences decision makers (Hudson \& Thal, 2013), especially the younger ones (Bizirgianni \& Dionysopoulou, 2013), and, based on their content analysis, they bring unique information about the perception of their visitors' destinations (Lai, 2011; Lai \& To, 2015). The increasing importance of social media emphasizes strategic analyses of the way the NTO marketing is developed, as Nguyen and Wang (2011) indicate for Sweden, Cowhey, O'leary and O'connor (2013) for Ireland, Vazou (2014) for Greece, Brown (2015) for Islamic countries OIC, and Andonian et al. (2016) for Japan. A marketing segmentation approach in social media to (potential) visitors is being developed (Amaro, Duarte, \& Henriques, 2016).
In the presented study, both qualitative and quantitative research strategies were implemented to analyse in which way NTOs in the countries with the highest number of international visitors use the social media in their marketing. The secondary research was based on the data extracted from studies published by Hays, Page and Buhalis (2013), Alizadeh and Isa (2015) and others on the use of social media in destination marketing. The primary research was conducted directly in the space of social media (the social media accounts of the selected NTOs).

\section{Theoretical Basis}

Tourism research needs an interdisciplinary approach, especially if it is intended to describe and analyse the researched phenomenon in a holistic way (Pásková, 2017). This contribution stems from both primary and secondary research and its theoretical background is premised on several human science disciplines and multimedia theory. The constructively realistic approach to multimedia related theoretical background has assisted to arriving at critical view on the basic effects that multimedia systems have on people, knowledge transfer, entertainment, and data processing (Hoogeveen, 1997). It also facilitated the insight needed for correct interpretation of collected research data. The methods of cognitive science applied in tourism (Ankomah \& Crompton, 1992; Zelenka et al., 2014; Zelenka, Pásková \& Husáková, 2015), tourism psychology (Cohen, 1972; Plog, 1977; Smith, 1990; Hahn \& Kagelmann, 1993), in particular the perception and motivation related theoretical concepts (Mansfeld, 1992; Fodness, 1994; Garrod, 2008; Munar \& Jacobsen, 2014; Madden, Rashid, \& Zainol, 2016), served for both design and implementation of the research as well as for the analytic work and the final synthesis of research results. 
In the present globalized world, the need for deep understanding of the cognitive and psychological aspects of social media is increasingly growing. The application of the artificial Intelligence, cognitive science as well as information and communication technologies is experiencing a significant increase of importance, both in theory and practice (Zelenka et al., 2014; Zelenka, Pásková, \& Husáková, 2015). The social media are used in tourism for a different purpose and in a different context: in the search for tourism related information (Zeng \& Gerritsen, 2014; Mukherjee \& Nagabhushana, 2016; Felix, Rauschnabel, \& Hinsch, 2017), in tourism related knowledge sharing (Nezakati et al., 2015), in strategic marketing (Felix, Rauschnabel, \& Hinsch, 2017), and in communication among tourism actors (Alizadeh \& Isa, 2014; 2015). In context of process of the tourism transformation to the necessary social needs of the inhabitants in developed countries, Larsen, Urry and Axhausen (2007) emphasize the role of social media in the socialization of tourists. Social media represents for tourism a real "megatrend" having a significant impact on the decision-making of tourism participants, tourism management and on-going activities (Leung et al., 2013). For example, motivation to visit the destination is based also on the social media user-generated content (UGC). An inspiration for other travellers belongs among the motivations to share the content of social media contribution (Munar \& Jacobsen, 2014). The results of the comparative research analysing the studies from the years of 2007 to 2011 (Leung et al., 2013) have demonstrated the strategic importance of social media for tourism competitiveness. The comparative analysis of these studies has also revealed the main topics of social media research such as the influence of social media on the decisionmaking of potential tourism participants and the roles of social media in the promotion, research and management of tourism.

The important motivational and informational role plays social media in dissemination of e-WOM (Electronic wordof-mouth), as shown e.g. by Trusov, Bucklin and Pauwels (2008), Litvin, Goldsmith and Pan (2008), Jalilvand, Esfahani and Samiei (2011), Tham, Croy and Mair (2013), Wang (2015) and Abubakar (2016). Sotiriadis and

\section{Fig. 1: Conceptual model of e-WOM}

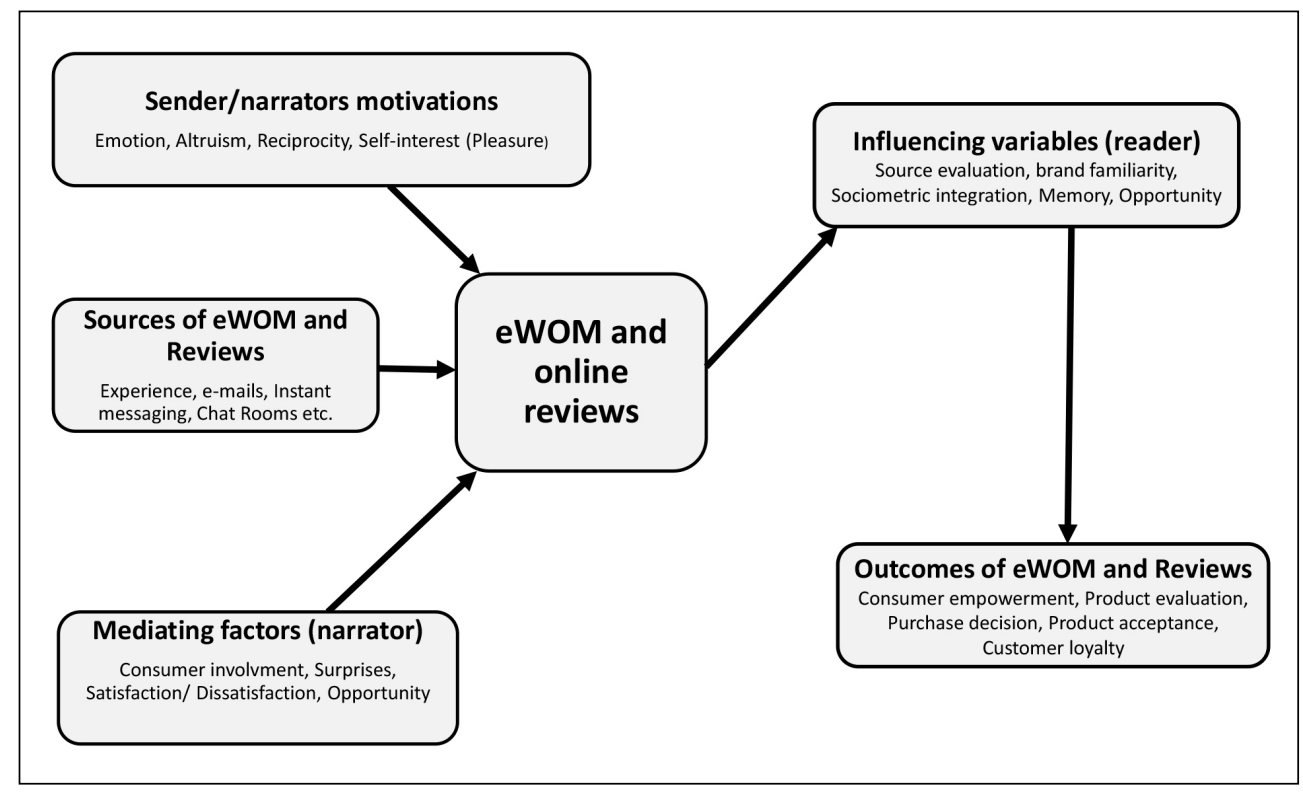


van Zyl (2013) elaborated a conceptual model of the e-WOM (Fig. 1), interlinking sources of eWOM, sender motivations and mediating factors with variables influencing the reader perceptions. The outcomes of eWOM, which include the destination evaluation, destination acceptance, decision of destination visit, and destination visitors' loyalty, have inspired the interpretation of the present study. The e-WOM, both personal and commercial, has, according to various studies (e.g. Ishida, Slevitch \& Siamionava, 2016), a motivational and persuasive potential, comparable to a personto-mouth personal contact. Among the basic forms of the e-WOM belong review sites (their multifactorial relationships stressed by Xiang et al., 2017), some types of social media (especially Facebook, Twitter as demonstrated e.g. by Sotiriadis \& van Zyl, 2013) and tourismfocused blogs. According to Sotiriadis and van Zyl (2013), Twitter must be seen as one of the channels of integrated marketing communications. Brian (2010) emphasized the importance of Twitter for marketing on communication among tourism participants as well as sharing and comparing their travel experience.

The use of social media represents an important part of destination marketing (e.g. Stankov, Lazić, \& Dragićević, 2010; Dwivedi, Yadav, \& Venkatesh, 2011; Hays, Page, \& Buhalis, 2013; Pike \& Page, 2014; Alizadeh \& Isa, 2014; 2016; Rahman, 2017). The use of the social media in destination marketing is very dynamic, especially for the NTOs. For comparison, in $2010,41.5 \%$ of the NTOs worldwide (Dwivedi, Yadav, \& Venkatesh, 2011) used at least one social medium and the most commonly used social media were Facebook (79\%), Twitter (62\%), YouTube (59\%) and Flickr (26\%). A similar study, conducted four years later (Alizadeh \& Isa, 2014; 2015), found that in 2014 nearly $67 \%$ of the NTOs in the world and even $95.5 \%$ of the NTOs in Europe had used social networks. The extent and mode of the use of individual social media in the NTOs' practice should apply the updated scientific findings.

As proved by previous research (e.g. Popescu, 2014; Alizadeh \& Isa, 2014; 2015; Mariani, Di Felice, \& Mura, 2016), Facebook represents an important marketing tool for destination management and specifically, for destination management organizations. Facebook is also used extensively for searching and intermediation of tourism information (Xiang \& Gretzel, 2010; Enter \& Michopoulou, 2013; Bulencea \& Egger, 2014), especially about destination attractiveness (Bulencea \& Egger, 2014). Facebook is also used in planning of holidays and trips as well as one of modes of sharing travel experiences with other tourism participants (Enter \& Michopoulou, 2013). YouTube is a social multimedium with a strong influence on conscious and unconscious perception of its users and it serves as a marketing tool in tourism industry (Reino \& Hay, 2011). As reported by Tussyadiah and Fesenmaier (2009), the online-shared videos significantly affect the imagination and daydreaming of their viewers and they thus represent a significant mediator or catalyser of both conscious and subconscious motivation to visit the destination. Because of the multimediality and the experience of interacting with online-shared videos on YouTube, its potential for viral marketing, viral marketing techniques as well as its social determinants is considered (e.g. Camarero \& José, 2011). To use YouTube effectively, it is important to compare, in relation to its users' decisionmaking, the impact of user-generated videos versus impact of those created by NTOs (respectively by destination management organizations) on the destination image (Lim, Chung, \& Weaver, 2012). The similar mode of comparison of the attractiveness of these videos (Hautz et al., 2014) indicates, that users are interested in videos created by users, particularly, which regards the lower-quality videos. For videos of high technical quality, the difference is relatively small. Therefore, the results presented by Hautz et al. (2014) indicate a significant marketing potential of high quality videos of commercial / public benefit organizations (e.g. NTOs, destination management organizations) on YouTube.

\section{Methodology}

The purpose of this research was to find out how social media are used by the NTOs of the countries with the highest visitor numbers of international tourists. This objective was achieved through both quantitative and qualitative analysis of these NTOs' use of social media (Fig. 2). The intention behind was to discover which approaches to the social media use should be applied for the effective destination marketing on the national level. 


\section{Fig. 2: Diagram of realized research and its results}

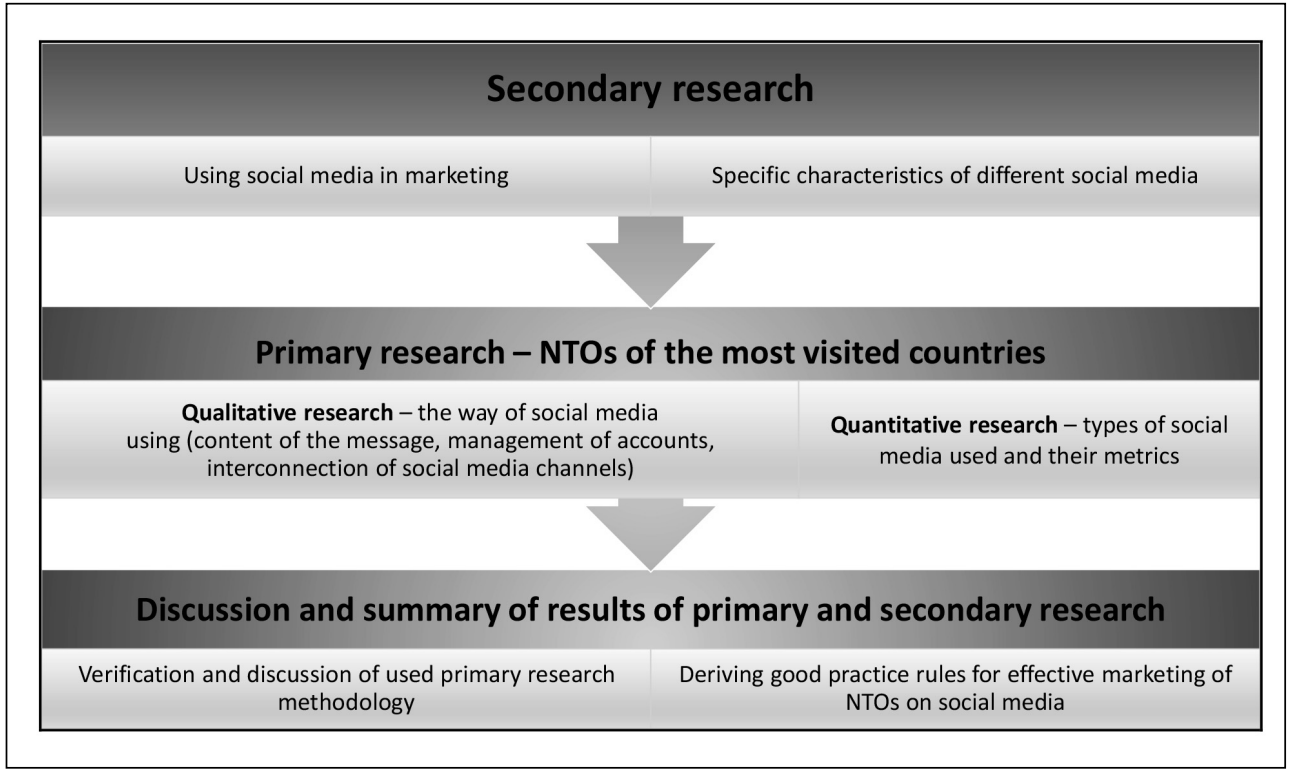

Source: own elaboration

According to UNWTO (2017, p. 6), the top ten most visited countries in the world in 2016 were the following countries: France, USA, Spain, China, Italy, Great Britain, Germany, Mexico, Thailand and Turkey.

The basic criterion for choosing the type of analysed social media was their use by the NTOs identified in the relevant research studies (Stankov, Lazić, \& Dragićević, 2010; Dwivedi, Yadav, \& Venkatesh, 2011; Hays, Page, \& Buhalis, 2013; Alizadeh \& Isa, 2014). Additional criterion was technological development of the social media and the extent of their use over the last three years. Thus, the research focused on the basic aspects of using Facebook (FB), YouTube (YT), Twitter (TW), Flickr (FL), Instagram (IM), Pinterest (PN), Google+ $(\mathrm{G}+)$ and Snapchat (SC) by NTOs in the destination marketing. The selected, more detailed both quantitative (metrics of the official NTOs' accounts) and qualitative (content and conceptual) analyses were conducted for social media with the highest potential for destination marketing: Facebook, Twitter, Instagram and YouTube. The use of Facebook, Twitter, and YouTube was evaluated in this way by Hays, Page and Buhalis (2013) and Alizadeh and Isa $(2014 ; 2015)$, while the use of Instagram in the NTOs' marketing was pre-analysed in the pilot research conducted by the authors. The key quantitative indicators were the rate of social media use for the official accounts of the selected NTOs, the extent of their connection to their website and the number of fans. The qualitative analysis of the social media use by NTOs concentrated on the content and conceptual focus of the contributions and the NTOs' collaboration with social media users. This more detailed analysis included also an assessment of the user-generated content (photos or videos), the NTOs' response rate to user queries, the history of social media use by the NTO, and the dynamics of its changes (e.g. how frequently are videos uploaded into a YouTube account) of the NTOs' accounts in the social medium.

The following research questions were formulated:

1. How do the basic metrics of the account of the selected NTOs differ in the most used social media?

2. What is the typical content and conceptual focus of the accounts' contributions of the 
selected NTOs in the most used social media and how does it differ among these NTOs?

3. What are the differences in the management of the accounts of the selected NTOs in the most used social media?

4. Can the responses to the three previous questions explain the higher fan base for the presentation of destinations in the social media?

The research was based on the analysis of the information freely available on social networks, partially in the form of content analysis and metrics identification and partially with the help of social media analytical software - Socialbakers. This software was used to analyse the NTOs' most successful contributions as well as the evolution of the NTOs' accounts' success over time. The three NTOs with the highest number of fans on Facebook (USA, Mexico and UK) were analysed by this software as well. Interactions per thousand fans per post and the type of the most favourite post for these NTOs were studied. Furthermore, sharing rate and popularity of photo/image/link/video posts for selected NTOs were analysed.

The criterion of linking the social media to the NTO's web consists in a clear link to the social medium on the introductive page, usually in the form of the icon of a given social medium.

\section{Results}

The results of this study describe the intensity and way in which the NTO of the most visited countries are using the most used social media for their marketing. The findings are giving not only the general picture of this use but also pointing out on the differences between the individual NTOs in using the individual social media as well as a their mutual comparison.

\subsection{Key Metrics of the Accounts of the Selected NTOs on Social Media}

The key quantitative features (metrics) of the accounts of the selected NTOs on social media are the social media usage levels (Tab. 1 and Fig. 3), the extent of their connection to the NTO (Tab. 1) and the number of fans (Tab. 1).

As Tab. 1 shows, Italy, Great Britain and Mexico use majority of the analysed social media for the official accounts of their NTOs and they have at the same time a link to them on their promotional web. The surprising finding was that the NTOs of two of the TOP 10 visited countries in the world, Thailand and Turkey, use very little social media. It is also the rule linking social media to the NTO's official promotional websites (Tab. 1).

As Fig. 3 shows, Facebook, YouTube, Twitter and Instagram are used by almost all the NTOs of the selected countries, except Thailand

\section{Tab. 1: NTO's use of social media}

\begin{tabular}{l|c|c|c|c|c|c|c|c}
\multirow{2}{*}{ NTO/ Country } & \multicolumn{7}{|c|}{ Social medium } \\
\cline { 2 - 9 } & FB & TW & IM & YT & PN & G+ & FL & SC \\
\hline France, Spain & $1 / 1$ & $1 / 1$ & $1 / 1$ & $1 / 1$ & 0 & 0 & 0 & 0 \\
\hline USA & $1 / 1$ & $1 / 1$ & $1 / 1$ & $1 / 1$ & 0 & $1 / 1$ & 0 & 0 \\
\hline China & $1 / 1$ & $1 / 1$ & 0 & $1 / 0$ & $1 / 1$ & 0 & 0 & 0 \\
\hline Italy, Mexico & $1 / 1$ & $1 / 1$ & $1 / 1$ & $1 / 1$ & $1 / 1$ & $1 / 1$ & 0 & 0 \\
\hline Great Britain & $1 / 1$ & $1 / 1$ & $1 / 1$ & $1 / 1$ & 0 & $1 / 1$ & $1 / 1$ & 0 \\
\hline Germany & $1 / 1$ & $1 / 1$ & $1 / 1$ & $1 / 1$ & 0 & 0 & 0 & $1 / 1$ \\
\hline Thailand & $1 / 0$ & 0 & 0 & 0 & 0 & 0 & 0 & 0 \\
\hline Turkey & E/N & E/N & E/N & $1 / 1$ & E/N & 0 & 0 & 0 \\
\hline
\end{tabular}

Source: own research on social media and promotional website of NTOs

Legend: $1 / 1$ - NTO uses a social medium and has a link to it on its promotional website, $1 / 0$ - NTO uses a social medium, but it does not link it to its own website, E/N - NTO has an account on a social medium, but it does not use it, $0-$ NTO has not any official account on a social medium 


\section{Fig. 3: The rate of active use of social media by the selected NTOs}

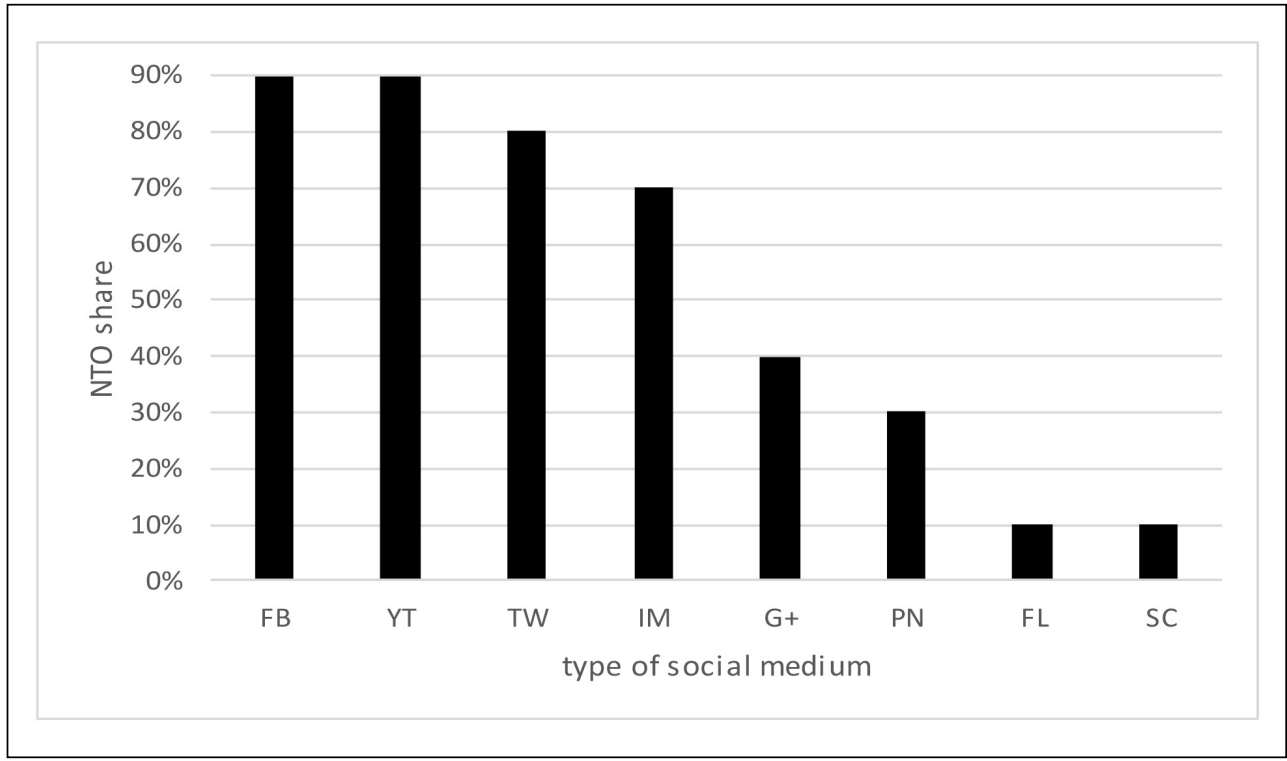

Source: own research

and Turkey. Facebook, Twitter, YouTube and Instagram are used most intensively by these NTOs, while their use of Google+, Pinterest, Flicker (Dwivedi, Yadav, \& Venkatesh, 2011), and Snapchat is rather passive and generally low. The realized analysis confirmed the growing role of Instagram in NTO's communication with users, as it has been indicated by the pilot research results and their comparison with the results of the research in 2013-2015 (Hays, Page, \& Buhalis, 2013; Alizadeh \& Isa, 2014; 2015).

The US, Mexican, British and German NTOs have the highest numbers of fans on their social media accounts, while the Chinese NTO uses social media in a limited way, and the NTO of Thailand uses them least, in fact it uses only Facebook (Tab. 2). Specific case represents the Turkish NTO, which displays links to its Facebook, Twitter, Instagram, YouTube, and Pinterest accounts on its promotional website, but it only uses YouTube with the relatively low posting rate of one video per month. For the researched NTOs all together, the order of their fans' numbers is as follows: Facebook, Twitter, Instagram and YouTube.

\subsection{Characteristics of the Management of NTOs' Social Media Accounts}

The key characteristics of the account management of the selected NTOs are presented in Tabs. 3 and 4 for the four most popular social media Facebook, Twitter, Instagram and YouTube ranked by countries according to the number of their international tourists. To characterize the management quality of these social media, the features typical for each of these media and reported at the most of the NTO accounts, were selected. These features describe the dynamics of the given account (response rate to user contributions, subscription frequency), account "age" (year of establishment), and account scope (number of messages and graphical/ multimedia content). Some of the NTOs do not present some of these data on Facebook and Twitter.

Only NTOs of the USA and Great Britain use to react immediately to the contributions placed on their Facebook account, Italian NTO responds within one hour, Chinese NTO within several hours, while the Spanish, German and Mexican NTOs react within one day (Tab. 3). All the analysed NTOs, except of NTOs of the 
Tab. 2: Number of the NTO's fans on social media as of 8. 10. 2017

\begin{tabular}{l|r|r|r|r}
\multicolumn{1}{c|}{ NTO/ Country } & \multicolumn{1}{c|}{ FB } & \multicolumn{1}{c|}{ TW } & \multicolumn{1}{c}{ IM } & \multicolumn{1}{c}{ YT } \\
\hline France & $1,526,227$ & 28,796 & 6,866 & not stated \\
\hline USA & $6,457,274$ & 30,535 & 60,020 & 16,968 \\
\hline Spain & $1,745,456$ & 281,704 & 276,770 & 12,869 \\
\hline China & 23,524 & 6,683 & 4,061 & 828 \\
\hline Italy & 448,994 & 115,158 & 56,969 & 7,534 \\
\hline Great Britain & $3,316,366$ & 367,026 & 346,219 & 15,046 \\
\hline Germany & $2,339,192$ & 46,542 & 153,061 & 6,324 \\
\hline Mexico & $5,161,340$ & $1,546,505$ & 141,471 & 24,582 \\
\hline Thailand & 290,422 & $\mathrm{NA}$ & $\mathrm{NA}$ & $\mathrm{NA}$ \\
\hline Turkey & 5,299 & 615 & 29 & 55 \\
\hline
\end{tabular}

Legend: $N A^{*}$ - the account does not exist

Tab. 3: NTOs' accounts management on Facebook and Twitter as of 8. 10. 2017

\begin{tabular}{l|c|c|c|c|c}
\multirow{2}{*}{ NTO } & $\begin{array}{c}\text { It usually responds } \\
\text { to the enquiry/ } \\
\text { reaction to } \\
\text { a contribution }\end{array}$ & $\begin{array}{c}\text { It posts own } \\
\text { contribution } \\
\text { (frequency) }\end{array}$ & $\begin{array}{c}\text { Year of } \\
\text { establishment }\end{array}$ & $\begin{array}{c}\text { Number } \\
\text { of tweets }\end{array}$ & $\begin{array}{c}\text { Number } \\
\text { of videos } \\
\text { or photos }\end{array}$ \\
\cline { 2 - 6 } France & \multicolumn{2}{|c|}{ FB } & \multicolumn{2}{c}{ TW } \\
\hline USA & Imot stated & daily & 2009 & 5,535 & 1,733 \\
\hline Spain & within one day & daily & 2008 & 33,268 & not stated \\
\hline China & within several hours & daily & 2013 & 2,171 & 771 \\
\hline Italy & within one hour & daily & 2011 & 15,403 & 4,789 \\
\hline Great Britain & immediately & daily & 2009 & 41,998 & not stated \\
\hline Germany & within one day & daily & 2008 & 11,976 & 3,071 \\
\hline Mexico & within one day & daily & 2010 & 15,630 & 3,432 \\
\hline Thailand & not stated & daily & $\mathrm{N}$ & & \\
\hline Turkey & not stated & several & 2010 & 7 & 2 \\
\hline
\end{tabular}

USA and Turkey, post their own contributions on their Facebook account daily, therefore, they constantly build brand awareness and stimulate fan base. All the NTOs link their Facebook account to their promotional website, while the Spanish, German, and Mexican NTOs place also their phone number on their Facebook account.

The Spanish and German NTOs have the longest history of Twitter use (beginning in 2008), while the freshest Twitter user is the Chinese NTO (starting in 2013). The highest 
Tab. 4: NTO accounts management on YouTube and Instagram as of 8. 10. 2017

\begin{tabular}{|c|c|c|c|c|c|c|c|c|}
\hline \multirow{3}{*}{$\begin{array}{c}\text { NTO/ } \\
\text { Country } \\
\text { France }\end{array}$} & \multicolumn{2}{|c|}{$\begin{array}{c}\text { Number of } \\
\text { contributions/ } \\
\text { videos }\end{array}$} & \multirow[t]{2}{*}{$\begin{array}{c}\text { Number } \\
\text { of the } \\
\text { videos } \\
\text { posted } \\
\text { per year }\end{array}$} & \multirow{2}{*}{\begin{tabular}{|c}
$\begin{array}{c}\text { Total num- } \\
\text { ber of video } \\
\text { views }\end{array}$ \\
YT
\end{tabular}} & \multirow{2}{*}{$\begin{array}{l}\text { Classification } \\
\text { of the videos }\end{array}$} & \multirow{2}{*}{$\begin{array}{c}\text { It puts } \\
\text { its own } \\
\text { tag } \\
\text { IM }\end{array}$} & \multicolumn{2}{|c|}{$\begin{array}{c}\text { Year of establish- } \\
\text { ment }\end{array}$} \\
\hline & IM & YT & & & & & YT & IM \\
\hline & 867 & 354 & 59 & $1,744,585$ & \multirow{4}{*}{ Thematically } & \multirow{8}{*}{ Yes } & 2011 & 2012 \\
\hline USA & 1,774 & 1,122 & 224 & $6,210,812$ & & & 2012 & 2012 \\
\hline Spain & 1,665 & 515 & 43 & $7,264,259$ & & & 2005 & 2014 \\
\hline China & 400 & 184 & 46 & 228,466 & & & 2013 & 2015 \\
\hline Italy & 1,065 & 392 & 65 & $11,520,085$ & $\begin{array}{l}\text { Thematically } \\
\text { and according } \\
\text { to language } \\
\text { (subtitles) }\end{array}$ & & 2011 & 2012 \\
\hline $\begin{array}{l}\text { Great } \\
\text { Britain }\end{array}$ & 1,619 & 390 & 78 & $4,238,229$ & \multirow{3}{*}{ Thematically } & & 2012 & 2014 \\
\hline Germany & 1,702 & 221 & 28 & $6,549,049$ & & & 2009 & 2013 \\
\hline Mexico & 993 & 344 & 38 & $15,331,267$ & & & 2008 & 2013 \\
\hline Turkey & 1 & 10 & 1 & 1,711 & No & No & 2010 & 2014 \\
\hline
\end{tabular}

Legend: "Puts your own tag" means that the NTO puts a tag on its account to encourage its submissions on user contributions (\#VisitTheUSA, \#MyFrance etc.).

number of tweets has the British NTO and the highest number of videos or photos is reported by the Italian NTO (Tab. 3). Selected NTOs, except of Turkey, are very active on this social media but their performance at Twitter is in reality a duplication of their activity on Facebook.

The NTOs of the USA, Germany and Spain showed the highest number of Instagram contributions in the time of this research. All of analysed NTOs except of the USA link their Instagram account to their promotional website and all of them, except of the Turkish NTO, put their own tag at their Instagram account (Tab. 4). The history of Instagram use of all the analysed NTOs is relatively short (between 2012 and 2015, Dwivedi, Yadav, \& Venkatesh, 2011). The activity on Instagram differs for selected NTOs, but with one to two posts a day on average, it means that they see potential in this social media.

The highest total number of videos currently placed on the YouTube account displays the
US NTO, the same pays for the number of videos placed there per year (Tab. 4). The NTO of the USA posts its own contributions on its YouTube account almost daily, the others NTOs irregularly or just several times a week. The displayed videos are classified in majority of cases thematically. The highest total number of views has the YouTube account of the Mexican NTO and the longest history of YouTube account use has the Spanish NTO (since 2005). Creating videos is usually more difficult and time consuming than just posting the commented photo, which explains the lower posting frequency (mostly around once a week) when compared with the rest of the selected social media.

\subsection{Content and Conceptual Features of the NTO Accounts on Social Media}

The Facebook is used by NTOs mainly for motivation to visit promoted destinations, especially by photos with nature motifs and promoting cultural and sporting events. The 
communication language is prevailingly English, which is the only language used by the NTOs of the USA, UK, China, Mexico and Turkey. The NTO of Spain uses Spanish and English. The Italian NTO posts its contributions in Italian and then translates them into English. Only the NTO of France presents its contributions exclusively in French, which significantly limits their use by international clients (see relatively low number of fans of this most visited country in Tab. 2). The presentation of German NTO is the most complex, which regards the type of its content. It uses a combination of photos, videos and articles. The collections of photos represent a basis for the Facebook presentation of the US NTO. The British NTO's presentation is based on the videos and the Turkish NTO's presentation consists mainly of the articles with the links to its promotional website. At the NTO of Mexico, the majority of photographs are accompanied by videos. The presentation of the Spanish NTO, alongside the promotion of the attractions of individual destinations, offers articles with examples of what can be experienced in Spain. The Chinese NTO, beside the attractiveness of its destinations, puts emphasis on local gastronomic specialties, and it links Facebook to Instagram users' contributions. The Italian NTO focuses exclusively on the promotion of its destinations by using photos and videos.

Using Socialbakers analytical software, authors made the following observations for the three NTOs with the highest number of fans on Facebook (USA, Mexico and UK):

- There is a significant difference in the number of interactions per thousand fans per post. For the NTO of the USA, the average number of interactions (liking, sharing or commenting) with these contributions is only 2.4 for a thousand fans, 37.1 for Mexico, and 16.4 for the United Kingdom.

- The distribution of interactions between all posts varies. For the NTO of the USA, only $5.9 \%$ of all interactions are created by sharing $(87.9 \%$ are responses/ ratings and $6.2 \%$ comments). A substantially higher extend of sharing contributions $(15.7 \%)$ is generated by the NTO of Mexico (response rate $80.6 \%$ and comment rate $3.8 \%$ ), and the United Kingdom with $10.4 \%$ sharing rate (response rate $85.0 \%$ and comment rate $4.6 \%$ ).

- Some regularities (e.g. high rate of sharing photo or image), as well as significant differences in the sharing of contributions according to their type were identified. On Facebook of the US NTO, the distribution of all shares is following: the photo or image post is shared at $70.4 \%$, the link at $22.2 \%$, and the video only at $7.4 \%$. In the case of the Mexican NTO, is distribution of all shares following: the photo or image is shared at $49 \%$, the video at $48.6 \%$, and the link at $2.4 \%$. In the case of the UK NTO, is distribution of all shares following: a photo or image is shared at $58.8 \%$, the link at $25.7 \%$, and the video at $15.5 \%$.

- In the case of NTOs of these three countries, 4 to $12 \%$ of the all the contributions are paid. This is rather low ratio, when compared with the rest of the analysed NTOs, which have a share of paid contributions at average $11 \%$, and with the extreme case of Russia with the value of this ratio at $45 \%$.

Predominant posts placed by the selected NTOs on Twitter have the form of destinations' promotion through photos and rarely in the form of video posts. Thematically, the presentation of the attractions of the destination is complemented by presentations of local gastronomic specialties and available activities. The UGC is used on this social media just sporadically.

A typical feature of the researched NTOs' presentation on Instagram is the fact that they display exclusively destinations' attractiveness there. Although the Instagram shows the added post to all the followers, for all NTOs, the ratio of "likes" at a given Instagram NTO's account for each new photo is just $2 \%$ to $4 \%$ of the total number of followers. For most NTOs, contributions to their Instagram account primarily include the UGC (photos, video) in the context of the win - win strategy. It is stimulated by the visibility of users (the NTO provides information who the contributor is) and the NTO intends to provide fast and efficient contributions of high quality. The NTOs use contributions placed at Instagram also on the other social networks, primarily on Facebook (for example, Mexico regularly duplicates photos from their Instagram to their Facebook account, including several photos at once).

Although YouTube is showing destinations to be visited, it is used by NTOs mainly to promote the positive tourists experiences and activities, sharing tourists' stories and, often, local products and gastronomy, cultural 
events and possible activities as well as other attractions of the country.

\section{Discussion}

Social media are, as confirmed by the findings of a number of authors (Hays et al., 2013; Lily et al., 2013; Királ'ová \& Pavlíčeka, 2015), intensively used in the NTO's marketing. The dominant social media in the NTOs' marketing of the ten most visited countries are Facebook, Twitter, Instagram and YouTube, and almost all of these NTOs have been using them for relatively long. The intensity, efficiency, and targeting of different user segments are increasing over time as the NTOs learn to make better use of social media marketing. At the same time, NTOs respond to changes in social media, which shows e.g. a new focus of the surveyed NTOs on Instagram. Compared to 2011 when Facebook, Twitter, YouTube and Flickr were the most used social media by NTOs (Dwivedi, Yadav, \& Venkatesh, 2011), in today NTOs marketing of the most visited countries, the important role of Instagram was established. On the contrary, the use of Flickr has declined. This can be explained by features more beneficial for destinations' promotion at Instagram with its structured thematic content (photos and videos) and effective support for sharing this content among users.

Facebook is generally known as the most widespread social media and the best one in creating fan base as well as in marketing with huge perfectly targeted marketing options (Novotová, 2018). On Facebook, in their posts, all the NTOs promote the attractiveness of destinations by means of photos or videos that present the range of activities in the destination, including the recognition of local gastronomy. There are also experiences of visitors to the destination and artistic photos of different kinds available on the NTOs' Facebook accounts.

Twitter is used mostly for brief stories and messages concerning destinations, especially the news (new attractions, up to date events, and immediate communication with visitors). On the other hand, Instagram represents a platform for sharing photos and videos where it is easy to raise an organic fan base with decent post activity. Photos laced on the Instagram, thanks to its technology, set up on various topics with a sophisticated tag structure, can effectively reach potential visitors.

The opportunities brought by using YouTube consist in new technologies (HDR,
3D video, $360^{\circ}$ video), which are often used by the researched NTOs. These NTOs also typically use thematic video classification according to the main types of motivation to visit the destination. Quantitative comparison of popularity of YouTube NTOs' accounts with most successful airlines on YouTube (Zelenka \& Hruška, 2018), brings also interesting facts. In this comparison, it appears that these NTOs' accounts on YouTube are considerably less frequently visited. The number of viewers on these accounts on YouTube is approximately ten times smaller, and number of video views is even hundreds of times lower when compared to the most successful airlines on YouTube.

Approach to the NTOs' marketing and management of their accounts differ on social media according to the type of social media and its typical features, however different NTOs use and fill the content in different way. On Facebook, most NTOs use only English and some of them use as a second language the native one (Italy, Spain). The same phenomenon can be observed on Twitter, YouTube and Instagram. In the future, the NTOs of the most visited countries (as e.g. the CzechTourism Agency currently offers) seem to be more likely to use segmentation by target markets with different language mutations, as well as by adapting the content of the message to the habits and requirements of the target market.

On YouTube, the NTOs vary which regards the frequency of uploading new videos France, Germany and the USA are active almost daily, while Spain, China, Turkey and the United Kingdom rather once per month or week. Another approach was chosen by the Italian and Mexican NTOs, which record new videos irregularly; they use to upload several videos at the same time and then they are inactive for several months. The management of YouTube accounts among the most visited countries in the world varies substantially and except France, Germany and the USA is not very systematic.

On Instagram, the NTOs behave similarly, which is probably related to the nature of this social network. All the analysed NTOs upload high-quality photos and occasionally video, with a high UGC share. With Twitter, these NTOs often duplicate Facebook information and posts. 


\section{Conclusions}

This research has helped to clarify how social media are used by the NTOs of the countries with the highest visitor numbers of international tourists. The knowledge of the pattern of the TOP 10 NTOs' behaviour on the social media can indicate the preferences of their users and reveal which approaches to the social media use could lead to the effective destination marketing on the national level. The analysis of the social media use by the NTOs of the ten selected countries has pointed out (in line with the theoretical knowledge on the importance of social media for tourism marketing) the importance of the social media role in their destination marketing. The research results also indicate (according to the researches' interpretations of the conceptual e-WOM provided in the chapter 1) that it is advisable to pay more attention to management and further development of the NTOs' social media accounts. The suitability of a combination of direct qualitative and quantitative research of the NTOs' content and social media metrics has been confirmed, complemented by the Socialbakers analytical software (tracking the evolution of social media over time, including users' activities on NTOs' accounts) to extend the spectrum of analyses realised.

In addition to YouTube and Facebook, Instagram has shown a great potential for the systematic destination marketing exercised by the NTO, as it has a significant advantage over still yet dominant Facebook in the posting view for all subscribers. While one can quickly get a large fan base on Facebook, then posting is restricted by Facebook rules and posts are only shown to limited number of fans. As a result, the analysed NTOs' accounts show that even though the number of subscribers is less than that of Facebook, the number of responses to the Instagram post is higher.

Future research, based on the these results for the NTOs' accounts of the most favourite destinations, could verify whether and to what extent the importance of sharing the photo/ picture posts and also the total size of the target groups of domestic and inbound tourism is being a factor in the success of the Facebook account. The complement research could be devoted to clarification of the relation between the NTOs' performance on the selected social media accounts and image of the given destination (and /or travel motivation) for the aforementioned tourists' target groups. Future research could also extend the NTOs' sample to compare if the countries with the lower number of international tourists' use the social media in the similar way as the top 10 NTOs. In this research, it would be helpful to focus on, among other things, differences in the management of social media accounts, their concepts of use and their content. The results of this research could then be correlated with the attendance of these accounts, with the number of their fans and their active response to contributions (both quantitative and qualitative analysis). Future research can also be inspired by qualitative research with a classification of the content of contributions placed in the social media (Pásková, Hruška, \& Zelenka 2018). The comparison with the use of social media in other tourism sectors (e.g. for airlines Zelenka \& Hruška, 2018) could lead to the generalization of the acquired knowledge.

The financial support of the Specific Research Project "Information and Knowledge Management and Cognitive Science in Tourism" of FIM UHK is gratefully acknowledged.

\section{References}

Abubakar, A. M. (2016). Does eWOM influence destination trust and travel intention: a medical tourism perspective. Economic Research-Ekonomska Istraživanja, 29(1), 598611. https://10.1080/1331677X.2016.1189841.

Alizadeh, A., \& Isa, R. M. (2014). An examination of use of social media in destination marketing. In Proceedings of the First AsiaPacific Conference on Global Business, Economics, Finance and Social Sciences (AP14Singapore Conference), Singapore, 1-3 August 2014.

Alizadeh, A., \& Isa, R. M. (2015). The use of social media in destination marketing: An exploratory study. Turizam, 63(2), 175-192.

Amaro, S., Duarte, P., \& Henriques, C. (2016). Travelers' use of social media: A clustering approach. Annals of Tourism Research, 59, 1-15. https://dx.doi.org/10.1016/j. annals.2016.03.007.

Andonian, A. et al. (2016). The future of Japan's tourism: Path for sustainable growth towards 2020. McKinsey Japan and Travel, Transport and Logistics Practice. Retrieved February 10, 2018, from https://www.mckinsey.com. 
Ankomah, P. K., \& Crompton, J. L. (1992). Tourism cognitive distance: A set of research propositions. Annals of Tourism Research, 19(2), 323-342. https://doi.org/10.1016/01607383(92)90084-3.

Bizirgianni, I., \& Dionysopoulou, P. (2013). The Influence of Tourist Trends of Youth Tourism through Social Media (SM) \& Information and Communication Technologies (ICTs). Procedia - Social and Behavioral Sciences, 73, 652-660. https://dx.doi.org/10.1016/j.sbspro.2013.02.102.

Brian, H. (2010). Twitter Twitter - But who is listening? A review of the current and potential use of Twittering as a tourism marketing tool. In CAUTHE 2010 20th International Research Conference: 'Challenge the Limits" (pp. 561575). University of Tasmania.

Brown, D. C. (2015). Effective Tourism Marketing Strategies: ICT-Based Solutions for the OIC Member Countries. Comcec Coordination Office. Retrieved February 10, 2018, from http://www.mod.gov.tr/Lists/RecentPublications/ Attachments/85/Effective \%20Tourism $\% 20$ Marketing\%20Strategies, $\% 20 I C T-B a s e d \% 20$ Solutions $\% 20$ for $\% 20$ the $\% 20$ OIC $\% 20$ Member\%20Countries.pdf.

Bulencea, P., \& Egger, R. (2014). Facebook it: Evaluation of Facebook's Search Engine for Travel Related Information Retrieval. In Z. Xiang \& I. Tussyadiah (Eds.), Information and Communication Technologies in Tourism 2014 (pp. 467-480). Springer: Cham.

Camarero, C., \& José, R. S. (2011). Social and attitudinal determinants of viral marketing dynamics. Computers in Human Behavior, 27(6), 2292-2300. https://dx.doi.org/10.1016/j. chb.2011.07.008.

Cohen, E. (1972). Towards a Sociology of International Tourism. Social Research, 39(1), 164-182.

Creevey, A., O'leary, S., \& O'connor, N. (2013). Social media: an innovative marketing tool in the Irish tourism industry? In 9th Annual Tourism and Hospitality Research in Ireland Conference (THRIC). Galway, 6-7th June. Galway: Galway-Mayo Institute of Technology.

Creevey, D., Bus, M., \& Bus, B. (2016). Examining the Role of Social Media within the Destination Marketing Framework Designed by Pike and Page (2014). ENTER 2016, 7. Retrieved January 21, 2018, from http://agrilife.org/ertr/ files/2016/01/ENTER2016_submission_165_.pdf.

Dwivedi, M., Yadav, A., \& Venkatesh, U. (2011). Use of Social Media by National
Tourism Organizations. A Preliminary Analysis. Information Technology \& Tourism, 13(2), 93-103. https://dx.doi.org/10.3727/10983051 2X13258778487353.

Enter, N., \& Michopoulou, E. (2013). An investigation on the Acceptance of Facebook by Travellers for Travel Planning'. e-Review of Tourism Research (e-RTR), 4. Retrieved January 21, 2018, from https://agrilifecdn.tamu.edu/ertr/ files/2013/03/enter2013_submission_32.pdf.

Felix, R., Rauschnabel, P. A., \& Hinsch, C. (2017). Elements of strategic social media marketing: A holistic framework. Journal of Business Research, 70, 118-126. https://dx.doi. org/10.1016/j.jbusres.2016.05.001.

Fodness, D. (1994). Measuring tourist motivation. Annals of Tourism Research, 21(3), 555-581. https://doi.org/10.1016/01607383(94)90120-1.

Garrod, B. (2008). Exploring Place Perception. A Photo-based Analysis. Annals of Tourism Research, 35(2), 381-401. https://doi. org/10.1016/j.annals.2007.09.004.

Hahn, H., \& Kagelmann, H. J. (1993). Tourismuspsychologie und Tourismussociologie: ein Handbuch zur Tourismuswissenschaft. München: Quintessenz.

Hautz, J. et al. (2014). Let Users Generate Your Video Ads? The Impact of Video Source and Quality on Consumers' Perceptions and Intended Behaviors. Journal of Interactive Marketing, 28(1), 1-15. https://dx.doi. org/10.1016/j.intmar.2013.06.003.

Hays, S., Page, S. J., \& Buhalis, D. (2013). Social media as a destination marketing tool: its use by national tourism organisations. Current Issues in Tourism, 16(3), 211-239. https://dx.doi.org/10.1080/13683500.2012.662215.

Hofacker, C. F., \& Belanche, D. (2016). Eight social media challenges for marketing managers. Spanish Journal of Marketing ESIC, 20(2), 73-80. https://dx.doi.org/10.1016/j. sjme.2016.07.003.

Hoogeveen, M. (1997). Toward a Theory of the Effectiveness of Multimedia Systems. International Journal of Human-Computer Interaction, 9(2), 151-168. https://doi. org/10.1207/s15327590ijhc0902_4.

Hudson, S., \& Thal, K. (2013). The Impact of Social Media on the Consumer Decision Process: Implications for Tourism Marketing. Journal of Travel \& Tourism Marketing, 30(1-2), 156-160. https://dx.doi.org/10.1080/10548408. 2013.751276. 
Ishida, K., Slevitch, L., \& Siamionava, K. (2016). The Effects of Traditional and Electronic Word-of-Mouth on Destination Image: A Case of Vacation Tourists Visiting Branson, Missouri. Administrative Sciences, 6(4), 1-17.

Jalilvand, M. R., Esfahani, S. S., \& Samiei, N. (2011). Electronic word-of-mouth: Challenges and opportunities. Procedia Computer Science, 3, 42-46. https://dx.doi. org/10.1016/j.procs.2010.12.008.

Királová, A., \& Pavlíčeka, A. (2015). Development of Social Media Strategies in Tourism Destination. Procedia - Social and Behavioral Sciences, 175, 358-366. https://dx.doi.org/10.1016/j.sbspro.2015.01.1211.

Lai, L. S. L. (2011). A Content-Based Analysis of Travellers' Social Media Websites. In Proceedings of the 2011 World Congress in Computer Science, Computer Engineering, and Applied Computing (pp. 547-553). Monte Carlo Resort, Las Vegas, Nevada, USA.

Lai, L. S. L., \& To, W. M. (2015). Content Analysis of Social Media: A Grounded Theory Approach. Journal of Electronic Commerce Research, 16(2), 138-152.

Lange-Faria, W., \& Elliot, S. (2012). Understanding the Role of Social Media in Destination Marketing. Tourismos: An International Multidisciplinary Journal of Tourism, 7(1), 193-211

Larsen, J., Urry, J., \& Axhausen, K. W. (2007). Networks and tourism: Mobile Social Life. Annals of Tourism Research, 34(1), 244-262. https://dx.doi.org/10.1016/j.annals.2006.08.002.

Leung, D. et al. (2013). Social Media in Tourism and Hospitality: a Literature Review. Journal of Travel \& Tourism Marketing, 30(1-2), 3-22. https://dx.doi.org/10.1080/10548408.201 3.750919 .

Lim, Y., Chung, Y., \& Weaver, P. A. (2012). The impact of social media on destination branding. Journal of Vacation Marketing, 18(3), 197-206. https://10.1177/1356766712449366.

Litvin, S. W., Goldsmith, R. E., \& Pan, B. (2008). Electronic word-of-mouth in hospitality and tourism management. Tourism Management, 29(3), 458-468. https://dx.doi. org/10.1016/j.tourman.2007.05.011.

Madden, K., Rashid, B., \& Zainol, N. A. (2016). Beyond the Motivation Theory of Destination. Tourism and Hospitality Management, 22(2), 247-264.

Mansfeld, Y. (1992). From motivation to actual travel. Annals of Tourism Research,
19(3), 399-419. https://doi.org/10.1016/01607383(92)90127-B.

Mariani, M. M., Di Felice, M., \& Mura, M. (2016). Facebook as a destination marketing tool: Evidence from Italian regional Destination Management Organizations. Tourism Management, 54, 321-343. https://dx.doi. org/10.1016/j.tourman.2015.12.008.

Mukherjee, A., \& Nagabhushana, M. (2016). Role of Social Media in Tourism Marketing. International Journal of Science and Research, 5(6), 2026-2033. https://dx.doi.org/10.21275/ v5i6.NOV164776.

Munar, A. M. (2012). Social Media Strategies and Destination Management. Scandinavian Journal of Hospitality and Tourism, 2(2), 101-120. https://dx.doi.org/10.1080/15022250.2012. 679047.

Munar, A. M., \& Jacobsen, J. K. S. (2014). Motivations for sharing tourism experiences through social media. Tourism Management, 43, 46-54. https://dx.doi.org/10.1016/j. tourman.2014.01.012.

Nezakati, H. et al. (2015). Review of Social Media Potential on Knowledge Sharing and Collaboration in Tourism Industry. Procedia - Social and Behavioral Sciences, 172, 120-125. https://dx.doi.org/10.1016/j. sbspro.2015.01.344.

Novotová, J. (2018). Exploring Customer Loyalty to Fashion Brands on Facebook Fan Pages. E\&M Ekonomie a Management, 21(1), 206-223. https://10.15240/tul/001/2018-1-014.

Nguyen, V. H., \& Wang, Z. (2011). Practice of Online Marketing with Social Media in Tourism Destination Marketing The case study of VisitSweden. Sweden, Master's dissertation. Retrieved January 21, 2018, from http://www. diva-portal.org/smash/get/diva2:424450/ fulltext02.

Palatková, M. (2012). Travel and Tourism Marketing - Review. Czech Journal of Tourism, 1(1), 30-52.

Pásková, M. (2017). Local and Indigenous Knowledge Regarding the Land Use and Use of Other Natural Resources in the Aspiring Rio Coco Geopark. IOP Conference Series: Earth and Environmental Science, 95(5).

Pásková, M., Hruška, J., \& Zelenka, J. (2018). YouTube as an airlines marketing tool. Czech Journal of Tourism, 8(1), in print.

Pike, S., \& Page, S. J. (2014). Destination Marketing Organizations and Destination Marketing: A Narrative Analysis of the Literature. 
Tourism Management, 41, 202-227. https://doi. org/10.1016/j.tourman.2013.09.009.

Plog, S. C. (1977). Why destination rise and fall in popularity. In E. M. Kelly (Ed.), Domestic and International Tourism. Wellesley, Mass: Institute of Certified Travel agents.

Popesku, J. (2014). Social Media as a Tool of Destination Marketing Organizations. Singidunum Journal of Applied Sciences, Supplement, 715-721.

Rahman, S. (2017). Tourism Destination Marketing Using Facebook as a Promotional Tool. IOSR Journal of Humanities and Social Science, 22(2), 87-90. https://doi. org/10.9790/0837-2202018790.

Reino, S., \& Hay, B. (2011). The Use of YouTube as a Tourism Marketing Tool. In Proceedings of the 42nd Annual Travel \& Tourism Research Association Conference (pp. 42-53). London, Ontario, Canada.

Smith,S.L.J.(1990).ATestofPlog'sAllocentric/ Psychocentric Model: Evidence from Seven Nations. Journal of Travel Research, 28(4), 40-43. https://doi.org/10.1177/004728759002800409.

Sotiriadis, M. D., \& Zyl, C. (2013). Electronic word-of-mouth and online reviews in tourism services: the use of twitter by tourists. Electronic Commerce Research, 13(1), 103-124. https:// doi.org/10.1007/s10660-013-9108-1.

Stankov, U., Lazić, L., \& Dragićević, V. (2010). The extent of use of basic Facebook user generated content by the national tourism organizations in Europe. European Journal of Tourism Research, 3(2), 105-113.

Tham, A., Croy, G., \& Mair, J. (2013). Social media in destination choice: Distinctive electronic word-of-mouth dimensions. Journal of Travel \& Tourism Marketing, 30(1-2), 144-155. https:// dx.doi.org/10.1080/10548408.2013.751272.

Trusov, M., Bucklin, R. E., \& Pauwels, K. (2008). Effects of Word-Of-Mouth versus Traditional Marketing: Findings from an Internet Social Networking Site [R. H. Smith School Research Paper No. RHS 06-065]. Retrieved January 21, 2018, from https://dx.doi.org/10.2139/ssrn.1129351.

Tussyadiah, I. P., \& Fesenmaier, D. R. (2009). Mediating Tourist Experiences: Access to Places via Shared Videos. Annals of Tourism Research, 36(1), 24-40. https://dx.doi. org/10.1016/j.annals.2008.10.001.

UNWTO. (2017). UNWTO Tourism Highlights: 2017Edition.https://doi.org/10.18111/9789284419029.

Vazou, E. (2014). From posters to posts: Greece moves beyond tourism campaigns to
eDestination branding. International Journal of Cultural and Digital Tourism, 1(1), 38-52.

Wang, P. (2015). Exploring the influence of electronic word-of-mouth on tourists' visit intention: A dual process approach. Journal of Systems and Information Technology, 17(4), 381395. https://doi.org/10.1108/JSIT-04-2015-0027.

Xiang, Z. et al. (2017). Acomparative analysis of major online review platforms: Implications for social media analytics in hospitality and tourism. Tourism Management, 58, 51-65. https://dx.doi. org/10.1016/j.tourman.2016.10.001.

Xiang, Z., \& Gretzel, U. (2010). Role of social media in online travel information search. Tourism Management, 31(2), 179-188. https://dx.doi.org/10.1016/j.tourman.2009.02.016.

Zelenka, J., \& Hruška, J. (2018). Ways and effectiveness of social media utilization by airlines. Tourism, 66(2), 227-238.

Zelenka, J., Olševičová, K., Cimler, R., Pásková, M., \& Procházka, J. (2014). Aplikace umělé inteligence a kognitivní vědy $v$ udržitelnosti cestovniho ruchu (Application of the Artificial Intelligence and Cognitive science in Sustainable Tourism). Hradec Králové: Gaudeamus.

Zelenka, J., Pásková, M., \& Husáková, M. (2015). Aplikace umělé inteligence, kognitivní vědy a informačních a komunikačních technologii $v$ udržitelném cestovním ruchu (Application of the Artificial Intelligence, Cognitive science, and Information and Communication Technologies in Sustainable Tourism). Hradec Králové: Gaudeamus.

Zeng, B., \& Gerritsen, R. (2014). What do we know about social media in tourism? A review. Tourism Management Perspectives, 10, 27-36. https://dx.doi.org/10.1016/j.tmp.2014.01.001.

Ing. Jan Hruška

University of Hradec Králové Faculty of Informatics and Management Department of Economics

Czech Republic jan.hruska.3@uhk.cz

Ing. Martina Pásková, Ph.D.

University of Hradec Králové Faculty of Informatics and Management Department of Recreology and Tourism

Czech Republic martina.paskova@uhk.cz 


\section{Abstract}

\section{HOW DO THE NATIONAL TOURISM ORGANIZATIONS USE THE SOCIAL MEDIA?}

\section{Jan Hruška, Martina Pásková}

The research was motivated by the growing importance of social media in the marketing of the National Tourism Organizations (NTO). The NTOs of the top ten most successful countries according to the number of international tourists in 2016 were selected as a research sample for analysis of the way, intensity and effectivity of the social media use in the destination marketing. The social media selected for above-mentioned analyses were Facebook, YouTube, Twitter, Flickr, Instagram, Pinterest, Google+ and Snapchat. The data collected for the analysis were publicly available data found on the NTO websites and in their social media accounts. The quantitative features of these NTO accounts (number of fans, number of their contributions, number of subscribers' responses), their management (especially the response to user contributions and inclusion of users of generated content) and the concept and focus of contributions generated by the NTO were evaluated and mutually compared. The analysis of the social media use by the NTOs of the ten selected countries has pointed out the importance of the social media role in their destination marketing. The selected NTOs use predominantly Facebook, YouTube, Twitter, and Instagram accounts, but only a few of them perform high quality management of these accounts. British, Italian and Mexican NTOs use the social media most, while Thailand and Turkey NTOs use them least. In addition to YouTube and Facebook, Instagram has shown a great potential for the systematic destination marketing exercised by the NTOs, as it has a significant advantage over still yet dominant Facebook in the posting view for all subscribers.

Key Words: Social media, national tourism organization, destination, marketing, Facebook.

JEL Classification: L83, M31.

DOI: 10.15240/tul/001/2018-4-015 